Prepared in cooperation with the Ohio Water Development Authority and Muskingum Watershed Conservancy District

\title{
Microbial Source Tracking Markers at Three Inland Recreational Lakes in Ohio, 2011
}

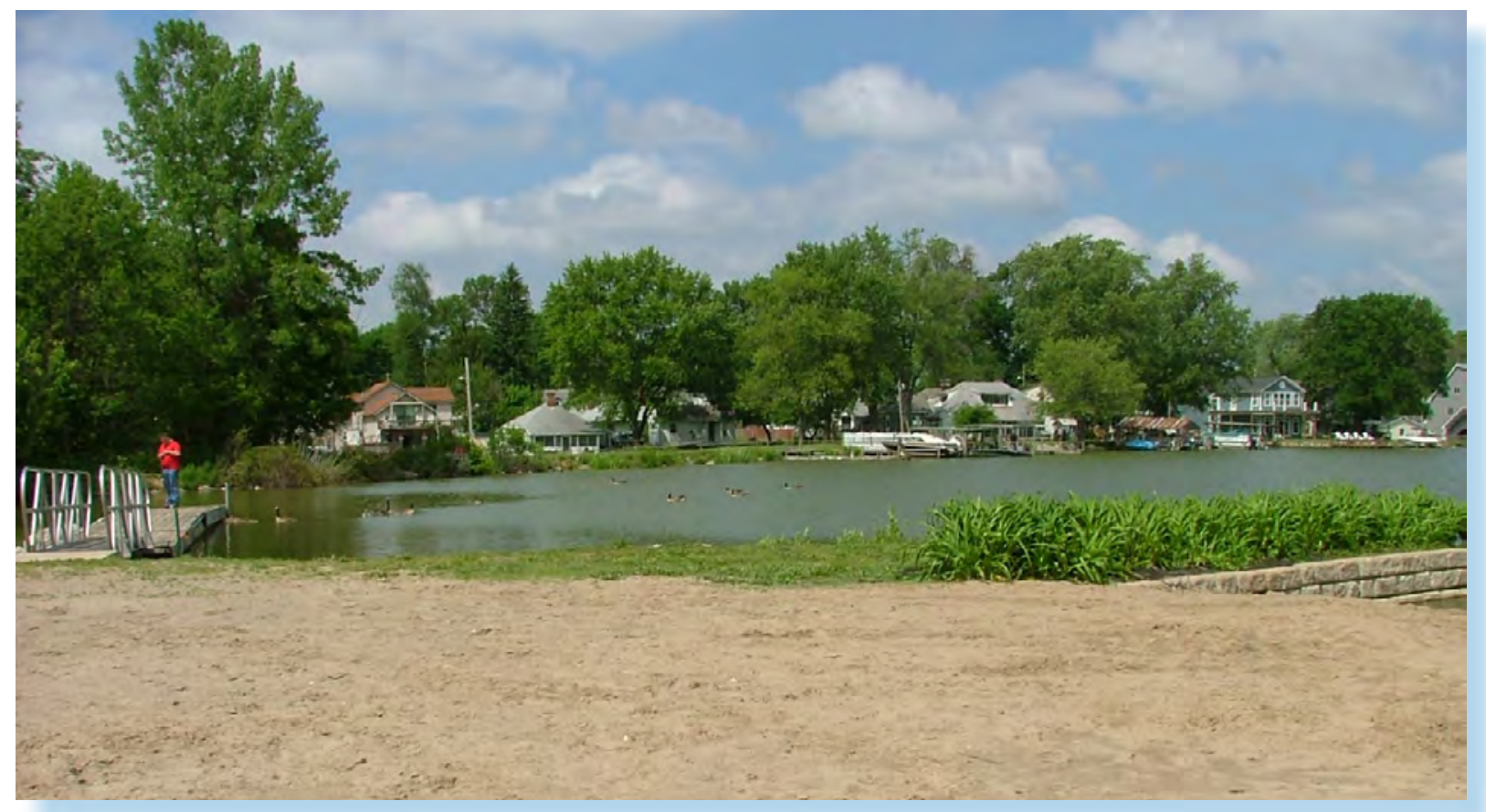

Open-File Report 2012-1222 
Cover image: View of area near Crystal Beach, Buckeye Lake, Ohio (photograph by Donna Francy, U.S. Geological Survey). 


\section{Microbial Source Tracking Markers at Three Inland Recreational Lakes in Ohio, 2011}

By Donna S. Francy and Erin A. Stelzer

Prepared in cooperation with the Ohio Water Development Authority and Muskingum Watershed Conservancy District

Open-File Report 2012-1222 


\section{U.S. Department of the Interior \\ KEN SALAZAR, Secretary \\ U.S. Geological Survey \\ Marcia K. McNutt, Director}

U.S. Geological Survey, Reston, Virginia: 2012

For more information on the USGS — the Federal source for science about the Earth, its natural and living resources, natural hazards, and the environment, visit http://www.usgs.gov or call 1-888-ASK-USGS.

For an overview of USGS information products, including maps, imagery, and publications, visit http://www.usgs.gov/pubprod

To order this and other USGS information products, visit http://store.usgs.gov

Any use of trade, product, or firm names is for descriptive purposes only and does not imply endorsement by the U.S. Government.

Although this report is in the public domain, permission must be secured from the individual copyright owners to reproduce any copyrighted materials contained within this report.

Suggested citation:

Francy, D.S., and Stelzer, E.A., 2012, Microbial source tracking markers at three inland recreational lakes in Ohio, 2011: U.S. Geological Survey Open-File Report 2012-1222, 8 p. 


\section{Contents}

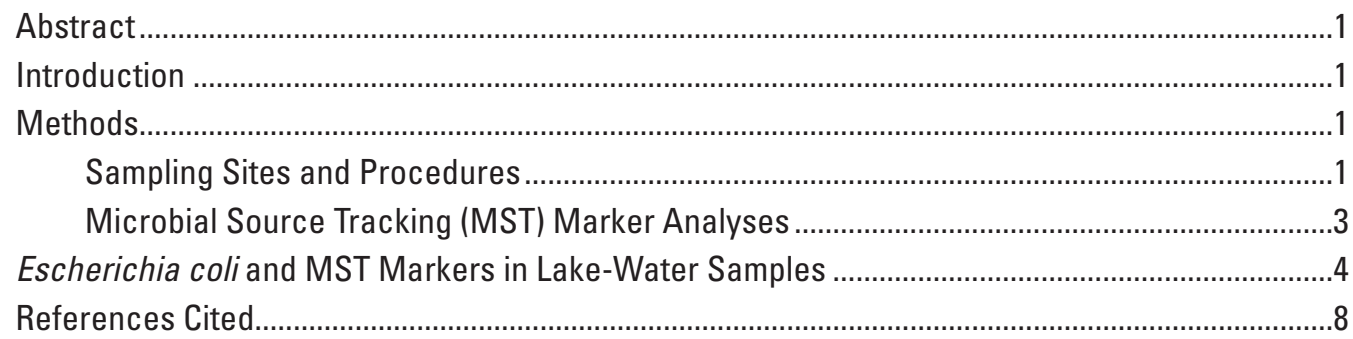

\section{Figures}

1. Map showing locations of the three study lakes in Ohio ...................................................

2. Graph showing percentages of samples with not detected, estimated quantities, and measured quantities of microbial source tracking markers: A, Buckeye Lake Crystal and Fairfield. B, Atwood Lake. C, Tappan Lake Main and ditch, 2011

\section{Tables}

1. Beach study sites and agencies responsible for sampling ..............................................

2. Standard curve characteristics for microbial source tracking (MST) markers................4

3. Quality-control field blank data for Escherichia coli and microbial source tracking (MST) markers, 2011.

4. Quality-control concurrent replicate data for Escherichia coli and microbial source tracking (MST) markers, 2011 .......................................................................

5. Concentrations of microbial source tracking (MST) markers in inland lake samples, 2011 


\section{Conversion Factors}

\begin{tabular}{lcl}
\hline \multicolumn{1}{c}{ Multiply } & By & \multicolumn{1}{c}{ To obtain } \\
\hline foot $(\mathrm{ft})$ & Length & meter $(\mathrm{m})$ \\
\hline & 0.3048 & \\
\hline liter $(\mathrm{L})$ & Volume & gallon (gal) \\
milliliter $(\mathrm{mL})$ & 0.2642 & fluid ounce $(\mathrm{oz})$ \\
microliter $(\mu \mathrm{L})$ & 0.03381 & milliliter $(\mathrm{mL})$ \\
\hline & 1,000 & \\
\hline gram $(\mathrm{g})$ & Mass & ounce, avoirdupois $(\mathrm{oz})$ \\
\hline
\end{tabular}

Temperature in degrees Celsius $\left({ }^{\circ} \mathrm{C}\right)$ may be converted to degrees Fahrenheit $\left({ }^{\circ} \mathrm{F}\right)$ as follows:

${ }^{\circ} \mathrm{F}=\left(1.8 x^{\circ} \mathrm{C}\right)+32$ 


\title{
Microbial Source Tracking Markers at Three Inland Recreational Lakes in Ohio, 2011
}

\author{
By Donna S. Francy and Erin A. Stelzer
}

\begin{abstract}
During the 2011 recreational season, samples were collected for $E$. coli and microbial source tracking (MST) marker concentrations to begin to understand potential sources of fecal contamination at three inland recreational lakes in Ohio-Buckeye, Atwood, and Tappan Lakes. The results from 32 regular samples, 4 field blanks, and 7 field replicates collected at 5 sites are presented in this report. At the three lakes, the ruminant-associated marker was found most often (57-73 percent of samples) but at estimated quantities, followed by the dog-associated marker (30-43 percent of samples). The human-associated marker was found in 14 and 50 percent of samples from Atwood and Tappan Lakes, respectively, but was not found in any samples from the two Buckeye Lake sites. The gull-associated marker was detected in only two samples, both from Tappan Lake.
\end{abstract}

\section{Introduction}

Identifying sources of fecal contamination at recreational beaches with elevated Escherichia coli (E. coli) concentrations is important for implementing appropriate remedial and control strategies and understanding human health risk of the water's use. Microbial source tracking (MST) is a term used for identifying sources of fecal contamination in the environment. MST techniques are based on the concept that intestinal systems of different warmblooded animals select for specific microbial populations in response to differences in diet and physiology. A widely used MST method is the use of hostassociated MST markers. For this method, a targeted genetic sequence of DNA is amplified by the polymerase chain reaction (PCR) into an amount that can be quantified. Host-associated MST markers have been identified from different groups of fecal bacteria, often from the genus Bacteroides, a bacterium abundant in the gut of warmblooded animals (Layton and others, 2006). Although the occurrence of host-associated MST markers has been investigated at coastal beaches (Bower and others, 2005; Wong and others, 2009; Edge and others, 2010), to our knowledge there are no published studies that use these markers to identify sources of fecal contamination at inland recreational beaches. Inland water bodies are popular swimming and boating destinations throughout the United States and, because of differences in size and hydrology, the water quality at inland lakes may be affected differently by contaminant sources than at coastal beaches.

This report describes the results of research by the U.S. Geological Survey (USGS), in cooperation with the Ohio Water Development Authority and the Muskingum Watershed Conservancy District, to begin to understand the sources behind elevated $E$. coli concentrations at three inland recreational lakes in Ohio. Thirty-two regular samples, four field blanks, and seven replicates were collected and analyzed for concentrations of E. coli, general Bacteroides, and host-associated markers for humans, ruminants, dogs, and gulls. The results are presented in this report. This work is part of a larger monitoring study that was done to determine whether predictive models for $E$. coli could be used to provide near-real-time assessments of water quality at inland recreational beaches.

\section{Methods}

\section{Sampling Sites and Procedures}

Samples were collected from five sites at three inland recreational lakes in Ohio (fig. 1, table 1) affected by elevated E. coli concentrations. Buckeye Lake is a shallow manmade reservoir in central Ohio constructed in the early 19th century for the Miami and Erie Canal, which connected the Ohio River with Lake Erie. Two beach sites were included at Buckeye Lake-Crystal and Fairfield. Sources of fecal contamination to Buckeye Lake are largely unidentified and may include birds and other wildlife, runoff from parking lots, and agricultural animals. Atwood Main and Tappan Main are sites at popular swimming beaches on reservoirs located in mixed recreational and agricultural areas in eastern Ohio. Potential sources of fecal contamination at Atwood Main include birds and discharge from a nearby intermittent stream. Potential sources of fecal contamination at Tappan Main include birds and other wildlife, runoff from the parking lot, and a lagoon wastewater treatment system that discharges effluent into a nearby ditch. The ditch drains into Tappan Lake near the beach. A sampling 


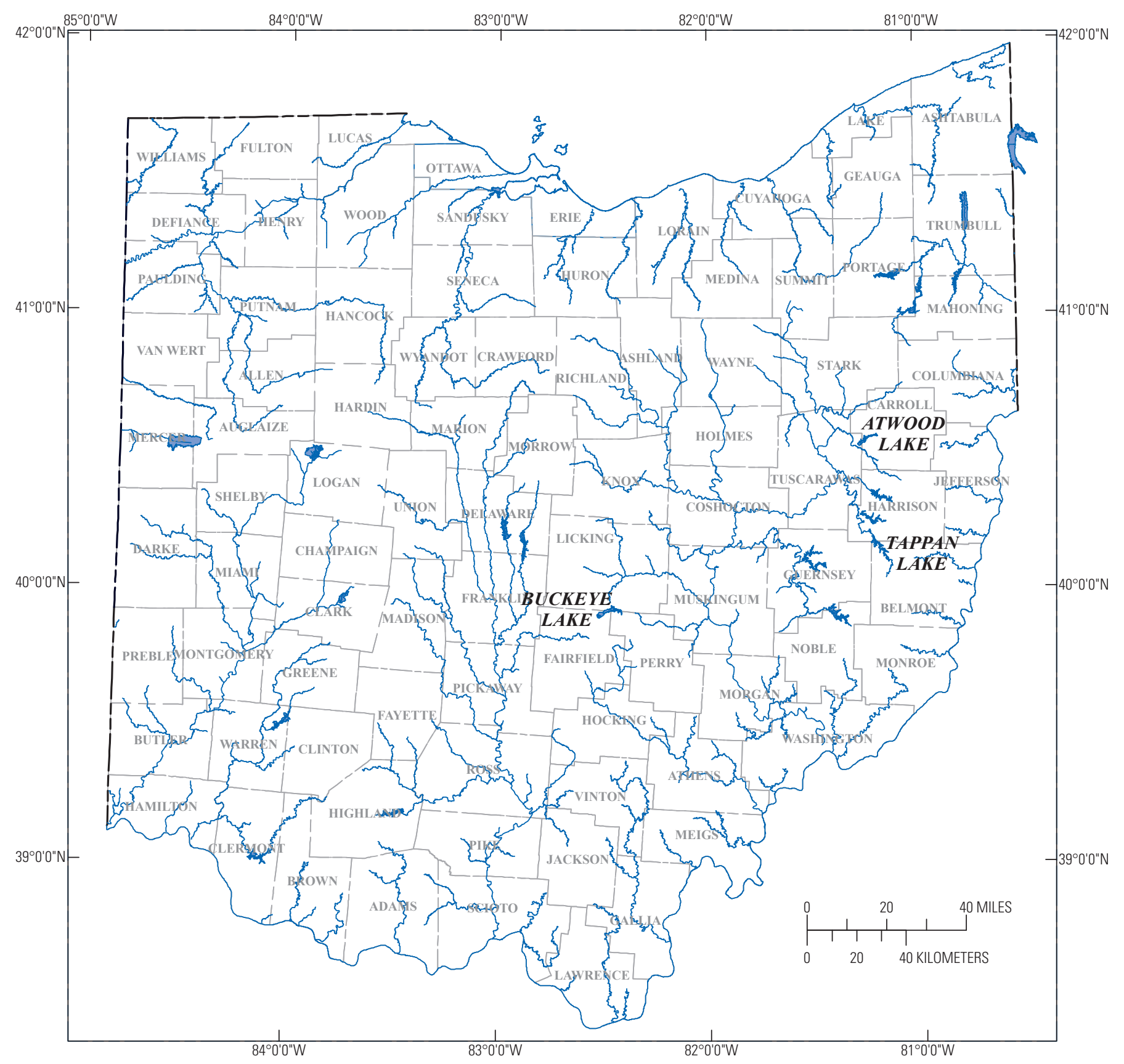

Figure 1. Locations of the three study lakes in Ohio. 
Table 1. Beach study sites and agencies responsible for sampling.

[MWCD, Muskingum Watershed Conservancy District, New Philadelphia, Ohio; USGS, U.S. Geological Survey, Columbus, Ohio]

\begin{tabular}{lclll}
\hline \multicolumn{1}{c}{ Site name } & $\begin{array}{c}\text { USGS site identification } \\
\text { number }^{1}\end{array}$ & Short name & Site description & $\begin{array}{c}\text { Sampled } \\
\text { by }\end{array}$ \\
\hline Atwood Lake Main Beach & 403219081155500 & Atwood Main & Popular bathing beach & MWCD \\
Buckeye Lake Fairfield & 395520082281500 & Buckeye Fairfield & Small beach & USGS \\
Buckeye Lake Crystal & 395557082283800 & Buckeye Crystal & Small beach & USGS \\
Tappan Lake Main Beach & 401926081105100 & Tappan Main & Popular bathing beach & MWCD \\
Tappan Lake ditch & 401910081111200 & Tappan ditch & Ditch & MWCD \\
\hline
\end{tabular}

${ }^{1}$ Corresponds to the latitude and longitude of each site.

site, Tappan ditch, was included to compare the sources of fecal contamination in the ditch to those at the swimming beach. The potential for human sources from wastewater at Buckeye Lake sites and at Atwood Main are unlikely because the communities around these reservoirs are served by sanitary sewer systems.

Data were collected during July-September 2011 by the USGS Columbus office (Buckeye Lake sites) or by the Muskingum Watershed Conservancy District (MWCD, Atwood and Tappan sites). Thirty-two samples for E. coli and MST markers were collected by using standard grab-sampling techniques (Myers and others, 2007) at 2-3 ft water depths, in areas used for swimming. A 1-L or 3-L sterile polypropylene sample bottle was filled with water about $1 \mathrm{ft}$ below the water surface, placed on ice, and transported by car or shipped overnight to the USGS Ohio Water Microbiology Laboratory (OWML) in Columbus, Ohio. In addition to regular sampling for $E$. coli and MST markers, four field blanks and seven replicates were collected and analyzed. If a MST marker was detected in one replicate and not the other, the result from the positive replicate was used; otherwise, an average of two replicates was used for data analysis.

Samples for E. coli were analyzed within 6 hours of collection at the OWML or MWCD office by use of the Colilert Quanti-Tray/2000 method (IDEXX Laboratories, Inc., Westbrook, Maine) and are reported in most probable number per 100 milliliters (MPN/100 mL). Sample processing and quality-control procedures are described in Myers and others (2007). Daily data on E. coli concentrations and MST markers were entered into the USGS National Water Information System (NWIS; data available at http://nwis.waterdata.usgs. gov/oh/nwis/qwdata).

\section{Microbial Source Tracking (MST) Marker Analyses}

Water samples for MST analyses were filtered onto Nucleopore polycarbonate filters (Whatman/GE Healthcare, Piscataway, N.J.) at the USGS Columbus laboratory within 24 hours of sample collection. Filters were preserved at $-70{ }^{\circ} \mathrm{C}$ in screw-cap vials with $0.3 \mathrm{~g}$ of acid-washed glass beads (Sigma, St. Louis, Mo.) until batch analysis was done after sample collection for the recreational season was completed. Samples were extracted by use of a DNA-EZ extraction kit (GeneRite, North Brunswick, N.J.) according to manufacturer's instructions, except that no prefilter was used and the final elution volume was $200 \mu \mathrm{L}$.

At the Columbus laboratory, DNA extracts were analyzed by qPCR for five MST markers: a general Bacteroides marker present in most warmblooded animals-AllBac (Layton and others, 2006); a human-associated Bacteroides markerHF183 (Seurinck and others, 2005); a ruminant-associated Bacteroides marker-BoBac (Layton and others, 2006); a dog-associated Bacteroides marker-BacCan (Kildare and others, 2007); and a gull-associated marker from the species Catellicoccus marimammalium - Gull2 (Sinigalliano and others, 2010). All qPCR assays were performed as described in the citations, with the exception of the Gull2, in which a double-quenched probe was used. The probe, which was labeled with an internal ZEN Quencher and an Iowa Black Quencher (Integrated DNA Technologies, Coralville, Iowa), was designed to reduce background and increase qPCR signal. Analyses by qPCR were run in duplicate by using $5 \mu \mathrm{L}$ of DNA extract and $20 \mu \mathrm{L}$ of master mix in an Applied Biosystems 7500 (Foster City, Calif.) thermal cycler. Depending on 
the MST assay, either TaqMan Universal PCR Master Mix or SYBR Green PCR Master Mix was used.

Plasmid standards for each MST assay were used to establish standard curves for quantification of MST markers. These were constructed by insertion of PCR-amplified marker sequences into the pCR4 TOPO E. coli plasmid vector (Invitrogen, Carlsbad, Calif.). The plasmid DNA was extracted and purified from E. coli cells by using the QIAPrep Spin Miniprep Kit (Qiagen, Valencia, Calif.). Copy number was calculated from DNA concentration, measured by use of the PicoGreen assay (Invitrogen, Carlsbad, Calif.), and the molecular weight of the plasmid. Sample results were reported as copies per 100 milliliters (copies/100 mL). Standard curve characteristics are included in table 2.

Laboratory quality-control samples included a processing blank (phosphate-buffered water processed with the water samples when filtered), an extraction blank (GeneRite Elution Buffer processed with filtered water samples during each batch of DNA extraction), a no-template control (molecular-grade water included on each qPCR plate), and positive controls (plasmid-based standard curves included in each qPCR run). Matrix inhibition was tested by using matrix spikes, as described in Stoeckel and others (2011).

\section{Escherichia coli and MST Markers in Lake-Water Samples}

Quality-control samples for E. coli and MST markers were collected to aid in data interpretations. In the four field blanks, sample results were below detection for all but one sample (table 3). For HF183 (human), an estimated concentration of 400 copies/100 mL was found in one field blank sample. Seven concurrent replicates for E. coli and MST markers were collected (table 4 ), and the absolute value $\log _{10}$ differences (AVLD) were calculated for each replicate pair when at least one replicate included a detection. The ranges of AVLDs for AllBac and Gull2 markers (0.01-0.51 copies/100 mL) were similar to the range of AVLDs for E. coli

Table 2. Standard curve characteristics for microbial source tracking (MST) markers.

[Dynamic range and limit of detection are reported in copies/reaction]

\begin{tabular}{lccccc}
\hline $\begin{array}{c}\text { MST } \\
\text { marker }\end{array}$ & $\begin{array}{c}\text { Number of } \\
\text { compiled } \\
\text { curves }\end{array}$ & $\begin{array}{c}\text { Dynamic } \\
\text { range }\end{array}$ & $\begin{array}{c}\text { Amplification } \\
\text { efficiency } \\
\text { (percent) }\end{array}$ & $\begin{array}{c}\mathbf{R}^{2} \\
\text { value }\end{array}$ & $\begin{array}{c}\text { Limit of } \\
\text { detection }\end{array}$ \\
\hline AllBac & 13 & $4.08 \times 10^{2}-8.72 \times 10^{7}$ & 92 & 0.997 & 8.1 \\
BacCan & 7 & $4.84 \times 10^{1}-7.70 \times 10^{6}$ & 89 & 0.999 & 42.2 \\
BoBac & 16 & $3.62 \times 10^{1}-6.38 \times 10^{6}$ & 90 & 0.996 & 3.2 \\
Gull2 & 2 & $5.52 \times 10^{1}-5.52 \times 10^{6}$ & 82 & 0.997 & 1 \\
HF183 & 19 & $2.26 \times 10^{1}-6.06 \times 10^{6}$ & 98 & 0.996 & 6.3 \\
\hline
\end{tabular}

Table 3. Quality-control field blank data for Escherichia coli and microbial source tracking (MST) markers, 2011.

[Escherichia coli (E. coli) are reported in most probable number per 100 milliliters (MPN/100 mL); MST markers are reported in copies per 100 milliliters (copies/100 mL); <, less than; - , not done; E, estimated value]

\begin{tabular}{llcccccc}
\hline Date & Sampling site & E. coli & $\begin{array}{c}\text { AllBac, } \\
\text { General }\end{array}$ & $\begin{array}{c}\text { HF183, } \\
\text { Human }\end{array}$ & $\begin{array}{c}\text { BoBac, } \\
\text { Ruminant }\end{array}$ & $\begin{array}{c}\text { BacCan, } \\
\text { Dog }\end{array}$ & $\begin{array}{c}\text { Gull2, } \\
\text { Gull }\end{array}$ \\
\hline $7 / 31$ & Atwood Main & $<1$ & $<160$ & E 400 & $<64$ & $<840$ & $<20$ \\
$8 / 14$ & Atwood Main & - & $<530$ & $<500$ & $<260$ & $<3,400$ & $<80$ \\
$8 / 30$ & Buckeye Crystal & $<1$ & $<160$ & $<130$ & $<64$ & $<840$ & $<20$ \\
$9 / 6$ & Buckeye Fairfield & $<1$ & $<530$ & $<430$ & $<210$ & $<2,800$ & $<67$ \\
\hline
\end{tabular}


(0.07-0.61 MPN/100 mL). For HF183, BoBac, and BacCan markers, however, most AVLDs were expressed as greaterthan values because one replicate was below detection. The largest measured AVLD (that was not a less-than value) was 0.87 copies $/ 100 \mathrm{~mL}$ for BoBac.

In all, 32 samples were collected for E. coli and MST markers - 15 from Buckeye Lake sites (Crystal and Fairfield) and 17 from MWCD sites (Atwood and Tappan) (table 5). E. coli concentrations ranged from 19 to $3,000 \mathrm{MPN} / 100 \mathrm{~mL}$, and eight samples exceeded the single-sample bathing-water concentration of $235 \mathrm{MPN} / 100 \mathrm{~mL}$ (Ohio Department of Health, 2011). The general marker (AllBac) was detected in all samples, with concentrations ranging from 1,000 to 590,000 copies $/ 100 \mathrm{~mL}$. As found by Pearson's correlation analysis, $\log$ concentrations of the general marker were not significantly related to $\log E$. coli concentrations $(\mathrm{r}=0.22, \mathrm{p}=0.2319)$.

Concentrations of host-associated MST markers were placed into three categories: (1) below the detection limit for all markers or lowest blank value for HF183 (not detected), (2) detected, but value was estimated because marker was detected in one replicate and not the other or concentration was below the linear range (estimated quantity), and (3) detected and reported with certainty (measured quantity). Using these categories, the percentages of detections for human, ruminant, dog, and gull markers for Buckeye Lake, Atwood, and Tappan sites are shown in figure 2. The two Buckeye Lake sites (Crystal and Fairfield) and the two Tappan sites (Main and ditch) were combined because sources of fecal contamination and MST results were similar. The human marker was not detected at the two Buckeye Lake sites but was detected at Atwood and Tappan sites in 14 percent and 50 percent of samples, respectively (estimated and measured quantities combined). Detections of the human marker at Tappan may have been from the nearby wastewater treatment plant and at Atwood and Tappan from the swimmers themselves. Using Pearson's correlation analysis on data from the larger monitoring study, the number of swimmers was significantly related to E. coli concentrations at Atwood ( $\mathrm{r}=0.39$, $\mathrm{p}<0.0001)$ and Tappan $(\mathrm{r}=0.20, \mathrm{p}=0.0187)$. The ruminant marker was detected most frequently, in 73,57, and 60 percent

Table 4. Quality-control concurrent replicate data for Escherichia coli and microbial source tracking (MST) markers, 2011.

[AVLD is absolute value $\log _{10}$ difference between replicate A and B; Escherichia coli (E. coli) are reported in most probable number per 100 milliliters $(\mathrm{MPN} / 100 \mathrm{~mL}$ ); MST markers are reported in copies per 100 milliliters (copies/100 mL); <, less than; >, greater than; ND, not determined because there were two values below detection; - , not done]

\begin{tabular}{|c|c|c|c|c|c|c|c|c|c|c|}
\hline \multirow[b]{2}{*}{ Date } & \multirow[b]{2}{*}{ Site } & \multicolumn{3}{|c|}{ E. coli } & \multicolumn{3}{|c|}{ AllBac, General } & \multicolumn{3}{|c|}{ HF183, Human } \\
\hline & & A & B & AVLD & A & B & AVLD & A & B & AVLD \\
\hline $7 / 11$ & Atwood AM & 6 & 7 & 0.07 & 3,300 & 3,400 & 0.01 & 560 & $<220$ & $>0.41$ \\
\hline $7 / 31$ & Atwood PM & 500 & 820 & 0.21 & 12,000 & 27,000 & 0.35 & $<130$ & 300 & $>0.36$ \\
\hline $8 / 27$ & Atwood PM & 21 & 50 & 0.38 & 12,000 & 39,000 & 0.51 & $<430$ & $<430$ & ND \\
\hline $8 / 30$ & Crystal & 490 & 980 & 0.30 & 370,000 & 390,000 & 0.02 & $<430$ & $<430$ & ND \\
\hline $9 / 6$ & Fairfield & 19 & 15 & 0.10 & 780,000 & 400,000 & 0.29 & $<430$ & $<430$ & ND \\
\hline $7 / 25$ & Tappan Main & 4,900 & 1,200 & 0.61 & 87,000 & 72,000 & 0.08 & $<220$ & $<220$ & ND \\
\hline $8 / 7$ & Tappan Main & - & - & - & 160,000 & 490,000 & 0.49 & $<500$ & 850 & $>0.23$ \\
\hline
\end{tabular}

\begin{tabular}{|c|c|c|c|c|c|c|c|c|c|c|}
\hline \multirow[b]{2}{*}{ Date } & \multirow[b]{2}{*}{ Site } & \multicolumn{3}{|c|}{ BoBac, Ruminant } & \multicolumn{3}{|c|}{ BacCan, Dog } & \multicolumn{3}{|c|}{ Gull2, Gull } \\
\hline & & A & B & AVLD & A & B & AVLD & A & B & AVLD \\
\hline $7 / 11$ & Atwood AM & 440 & $<110$ & $>0.60$ & 3,000 & 2,400 & 0.10 & $<33$ & $<33$ & ND \\
\hline $7 / 31$ & Atwood PM & $<64$ & $<64$ & ND & 1,100 & $<840$ & $>0.12$ & $<20$ & $<20$ & ND \\
\hline $8 / 27$ & Atwood PM & $<210$ & $<210$ & ND & $<2,800$ & 3,700 & $>0.12$ & $<67$ & $<67$ & ND \\
\hline $8 / 30$ & Crystal & 2,300 & $<210$ & $>1.04$ & $<2,800$ & $<2,800$ & $\mathrm{ND}$ & $<67$ & $<67$ & ND \\
\hline $9 / 6$ & Fairfield & 3,600 & 490 & 0.87 & 8,700 & $<2,800$ & $>0.49$ & $<67$ & $<67$ & ND \\
\hline $7 / 25$ & Tappan Main & 290 & $<110$ & $>0.42$ & $<1,400$ & $<1,400$ & $\mathrm{ND}$ & 2,300 & 1,200 & 0.28 \\
\hline $8 / 7$ & Tappan Main & 1,600 & 4,400 & 0.44 & $<3,400$ & 9,600 & $>0.45$ & 570 & 570 & 0.00 \\
\hline
\end{tabular}


Table 5. Concentrations of microbial source tracking (MST) markers in inland lake samples, 2011.

[E. coli, Escherichia coli; A, average of two replicates; >, greater than; <, less than; R, value reported was detected in one field replicate but not in the second replicate; E, estimated value because it was detected in one replicate and not the other or was below the linear range; detections of AllBac, BoBac, BacCan and Gull2 are shaded]

\begin{tabular}{|c|c|c|c|c|c|c|c|c|}
\hline \multirow[b]{2}{*}{ Date } & \multirow[b]{2}{*}{ Time } & \multirow[b]{2}{*}{ Site } & \multirow[b]{2}{*}{$\begin{array}{c}\text { E. coli } \\
\text { (MPN/ } 100 \mathrm{~mL} \text { ) }\end{array}$} & \multicolumn{5}{|c|}{ MST markers (copies/100 mL) } \\
\hline & & & & $\begin{array}{c}\text { AllBac } \\
\text { (general) }\end{array}$ & $\begin{array}{c}\text { HF183 } \\
\text { (human) }\end{array}$ & $\begin{array}{c}\text { BoBac } \\
\text { (ruminant) }\end{array}$ & $\begin{array}{l}\text { BacCan } \\
\text { (dog) }\end{array}$ & $\begin{array}{l}\text { Gull2 } \\
\text { (gull) }\end{array}$ \\
\hline $7 / 11$ & $9: 55$ & Buckeye Crystal & 29 & 130,000 & $<500$ & E 1,300 & E 3,800 & $<80$ \\
\hline $7 / 17$ & $7: 05$ & Buckeye Crystal & 58 & 160,000 & $<500$ & E 550 & $<3,400$ & $<80$ \\
\hline $7 / 24$ & $7: 10$ & Buckeye Crystal & 130 & 390,000 & $<500$ & E 2,200 & $<3,400$ & $<80$ \\
\hline $7 / 30$ & $6: 55$ & Buckeye Crystal & 920 & 310,000 & $<370$ & E 670 & 4,900 & $<57$ \\
\hline $8 / 8$ & $8: 22$ & Buckeye Crystal & 24 & 160,000 & $<500$ & $<260$ & 44,000 & $<80$ \\
\hline $8 / 22$ & $7: 12$ & Buckeye Crystal & 650 & 310,000 & $<430$ & $<210$ & $<2,800$ & $<67$ \\
\hline $8 / 30$ & $8: 10$ & Buckeye Crystal & A 740 & A 380,000 & $<430$ & RE 2,300 & $<2,800$ & $<67$ \\
\hline $9 / 13$ & $10: 50$ & Buckeye Crystal & 39 & 330,000 & $<430$ & E 1,600 & $<2,800$ & $<67$ \\
\hline $7 / 17$ & $7: 38$ & Buckeye Fairfield & 19 & 180,000 & $<500$ & $<260$ & 5,100 & $<80$ \\
\hline $7 / 24$ & $8: 00$ & Buckeye Fairfield & 210 & 200,000 & $<500$ & E 1,100 & $<3,400$ & $<80$ \\
\hline $7 / 25$ & $10: 07$ & Buckeye Fairfield & 210 & 46,000 & $<500$ & E 520 & $<3,400$ & $<80$ \\
\hline $7 / 30$ & $7: 35$ & Buckeye Fairfield & 80 & 190,000 & $<370$ & E 540 & 7,400 & $<57$ \\
\hline $8 / 8$ & 8:02 & Buckeye Fairfield & 26 & 170,000 & $<500$ & $<260$ & $<3,400$ & $<80$ \\
\hline $8 / 22$ & 8:00 & Buckeye Fairfield & 39 & 180,000 & $<430$ & E 1,500 & $<2,800$ & $<67$ \\
\hline $9 / 6$ & $9: 33$ & Buckeye Fairfield & A 17 & A 590,000 & $<430$ & AE 2,000 & RE 8700 & $<67$ \\
\hline $7 / 11$ & 9:19 & Atwood Main & A 6 & AE 3,400 & RE 560 & RE 440 & A 2,700 & $<33$ \\
\hline $7 / 25$ & $9: 42$ & Atwood Main & 60 & 200,000 & $<220$ & Е 290 & $<1,400$ & $<33$ \\
\hline $7 / 31$ & $8: 47$ & Atwood Main & 32 & E 1,000 & $<130$ & Е 270 & $<840$ & $<20$ \\
\hline $8 / 14$ & 9:03 & Atwood Main & 32 & E 6,800 & $<500$ & $<260$ & $<3,400$ & $<80$ \\
\hline $7 / 31$ & $12: 41$ & Atwood Main & A 660 & A 20,000 & RE $300^{\mathrm{a}}$ & $<64$ & RE 1,100 & $<20$ \\
\hline $8 / 27$ & $14: 00$ & Atwood Main & A 36 & AE 26,000 & $<430$ & $<210$ & RE 3,700 & $<67$ \\
\hline $9 / 11$ & $13: 38$ & Atwood Main & 210 & 42,000 & $<430$ & Е 960 & $<2,800$ & $<67$ \\
\hline $7 / 11$ & $10: 54$ & Tappan Main & 201 & E 10,000 & $<220$ & E 190 & 12,000 & $<33$ \\
\hline $7 / 25$ & $10: 53$ & Tappan Main & A 3,000 & A 80,000 & $<220$ & RE 290 & $<1,400$ & A 1,800 \\
\hline $8 / 7$ & $13: 17$ & Tappan Main & 120 & A 320,000 & RE 850 & $\mathrm{AE} 3,000$ & RE 9,600 & AE 570 \\
\hline $8 / 14$ & $10: 24$ & Tappan Main & 96 & E 9,800 & 1,600 & $<64$ & $<840$ & $<20$ \\
\hline $8 / 15$ & $10: 17$ & Tappan Main & 21 & E 51,000 & $<500$ & E 420 & $<3,400$ & $<80$ \\
\hline $7 / 11$ & $11: 16$ & Tappan ditch & 340 & 45,000 & $<130$ & $<110$ & $<1,400$ & $<33$ \\
\hline $7 / 25$ & 11:09 & Tappan ditch & 120 & E 10,000 & $<220$ & $<110$ & $<1,400$ & $<33$ \\
\hline $8 / 7$ & $17: 53$ & Tappan ditch & 2000 & 590,000 & E 590 & $<260$ & $<3,400$ & $<80$ \\
\hline $8 / 14$ & $10: 39$ & Tappan ditch & $>2400$ & 65,000 & E 710 & E 930 & 5,100 & $<33$ \\
\hline $8 / 15$ & $13: 10$ & Tappan ditch & ND & 350,000 & 2,600 & E 550 & $<3,400$ & $<80$ \\
\hline
\end{tabular}

\footnotetext{
${ }^{a}$ Not considered a detection because it was below the value found in one field blank.
} 


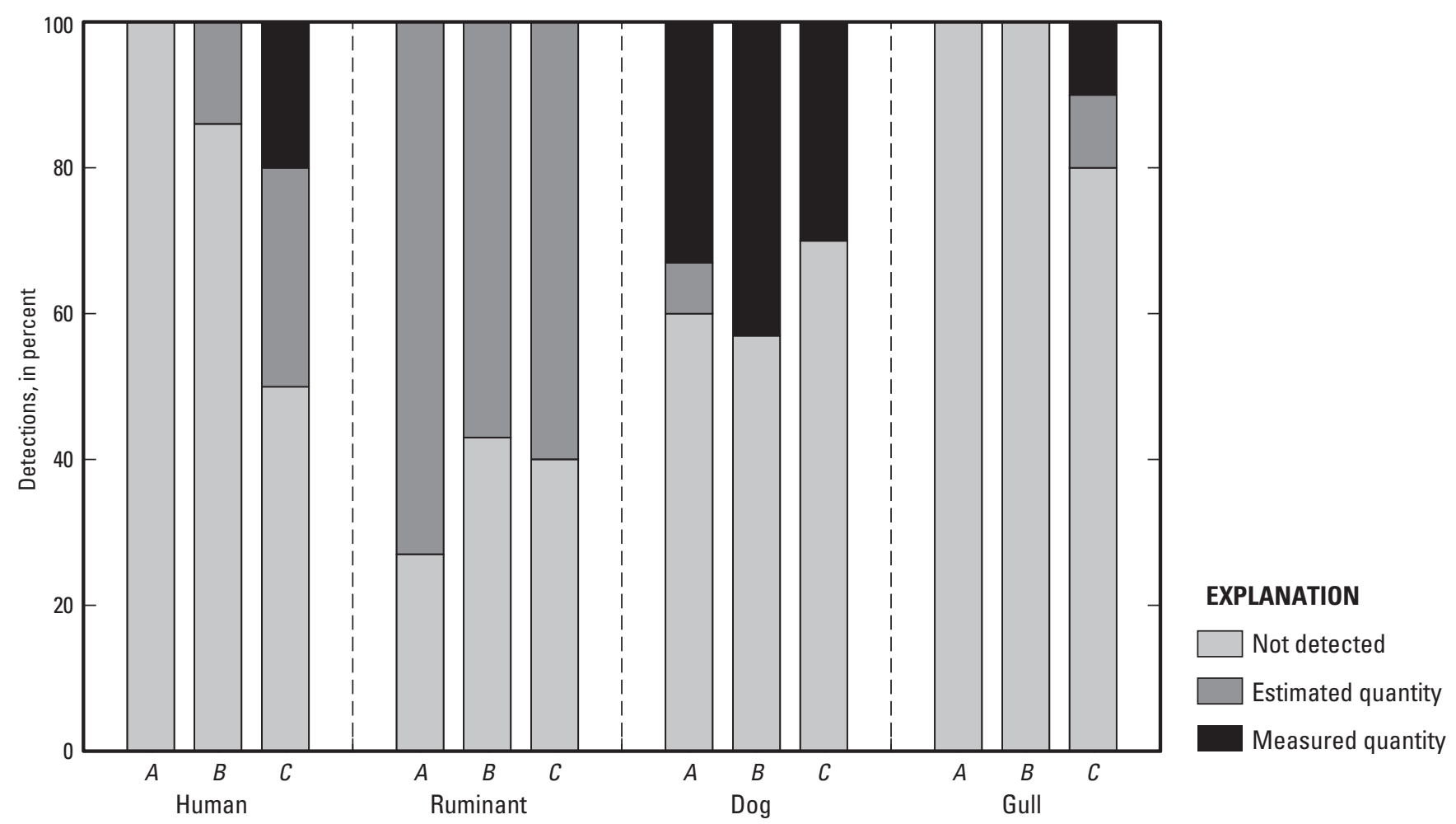

Figure 2. Percentages of samples with not detected, estimated quantities, and measured quantities of microbial source tracking markers: A, Buckeye Lake Crystal and Fairfield. B, Atwood Lake. C, Tappan Lake Main and ditch, 2011.

of samples from Buckeye Lake, Atwood, and Tappan, respectively, with some uncertainty in the measurements in all samples. The dog marker was detected in 40, 43, and 30 percent of samples from Buckeye Lake, Atwood, and Tappan, respectively. The gull marker was found in only two samples, both from Tappan Main. Results from the Wilcoxon rank-sum test indicated that the median concentrations of $E$. coli in samples with detections of markers were not significantly different from samples without detections of human $(p=0.24)$, ruminant $(\mathrm{p}=0.40)$, and $\operatorname{dog}(\mathrm{p}=0.15)$ markers. This test was not done on the gull marker because only two detections were found.

In this study, samples were collected and analyzed by use of microbial source tracking techniques to take the first step towards understanding sources of fecal contamination at five sites at three inland recreational lakes. It should be emphasized, however, that microbial source tracking techniques are in an experimental and developmental phase as a field of science specialization. Experts in the field recommend that multiple methods be used to characterize fecal contamination at a site and that source feces from the study area be tested to confirm that source-associated MST markers are present (Sargeant and others, 2011). Given these limitations, in order to fully characterize sources at the Buckeye Lake sites, more work needs to be done to collect samples under a variety of hydrological and environmental conditions, collect fecal source samples in the watershed, collect afternoon samples when swimmers are present, and apply other source tracking tools to establish multiple lines of evidence. 


\section{References Cited}

Bower, P.A., Scopel, C.O., Jensen, E.T., Depas, M.M., and McLellan, S.L., 2005, Detection of genetic markers of fecal indicator bacteria in Lake Michigan and determination of their relationship to Escherichia coli densities using standard microbiological methods: Applied and Environmental Microbiology, v. 71, no. 12, p. 8305-8313.

Edge, T.A., Hill, S., Seto. P., and Marsalek, J., 2010, Librarydependent and library-independent microbial source tracking to identify spatial variation in faecal contamination sources along a Lake Ontario beach: Water Science \& Technology, v. 62, no. 3, p. 719-727.

Kildare, B.J., Leutenegger, C.M., McSwain, B.S., Bambic, D.G., Rajal, V.B., and Wuertz, S., 2007, 16S rRNA-based assays for quantitative detection of universal, human-, cow-, and dog-specific fecal Bacteroidales-A Bayesian approach: Water Research, v. 41, no. 16, p. 3701-3715.

Layton, A., McKay, L., Williams, D., Garrett, V., Gentry, R., and Sayler, G., 2006, Development of Bacteroides 16S rRNA gene TaqMan-based real-time PCR assays for estimation of total, human, and bovine fecal pollution in water: Applied and Environmental Microbiology, v. 72, no. 6, p. 4214-4224.

Myers, D.N., Stoeckel, D.M., Bushon, R.N., Francy, D.S., and Brady, A.M.G., 2007, Fecal indicator bacteria (ver. 2.0): U.S. Geological Survey Techniques of Water-Resources Investigations, book 9, chap. A7, section 7.1, accessed October 2011 at http://pubs.water.usgs.gov/twri9A/.

Ohio Department of Health, 2011, Bathing beach monitoring program, accessed October 2011 at http://www.odh.ohio. gov/odhprograms/eh/bbeach/beachmon.aspx.
Seurinck, S., Defoirdt, T., Verstraete, W., and Siciliano, S.D., 2005, Detection and quantification of the human-specific HF183 Bacteroides 16S rRNA genetic marker with realtime PCR for assessment of human faecal pollution in freshwater: Environmental Microbiology, v. 7, no. 2, p. 249-259.

Sinigalliano, C.D., Fleisher, J.M., Gidley, M.L., Solo-Gabriele, H.M., Shibata, T., Plano, L.R., Elmir, S.M., Wanless, D., Bartkowiak, J., Boiteau, R., Withum, K., Abdelzaher, A.M., He, G., Ortega, C., Zhu, X., Wright, M.E., Kish, J., Hollenbeck, J., Scott, T., Backer, L.C., and Fleming, L.E., 2010, Traditional and molecular analyses for fecal indicator bacteria in non-point source subtropical recreational marine waters: Water Research, v. 44, no.13, p. 3763-3772.

Sargeant, D., Kamin, W.R., and Collyard, S., 2011, Review and critique of current microbial source tracking (MST) techniques: Olympia, Wash., Washington State Department of Ecology Publication No. 11-03-038, accessed September 2012 at https://fortress.wa.gov/ecy/publications/ SummaryPages/1103038.html, 66 p.

Stoeckel, D.M., Stelzer, E.A., Stogner, R.W., and Mau, D.P., 2011, Semi-quantitative evaluation of fecal contamination potential by human and ruminant sources using multiple lines of evidence: Water Research, v. 45, no. 10 , p. 3225-3244.

Wong, M., Kumar, L., Jenkins, T.M., Xagoraraki, I., Phanikumar, M.S., and Rose, J.B., 2009, Evaluation of public health risks at recreational beaches in Lake Michigan via detection of enteric viruses and a human-specific bacteriological marker: Water Research, v. 43, no. 4, p. 1137-1149. 



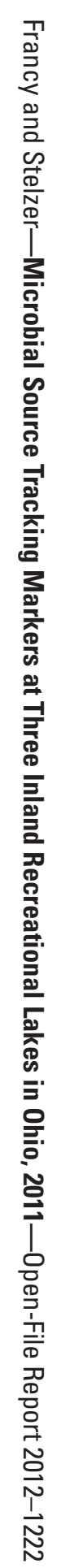

